\title{
The Relationship Between Accounting Information in the Financial Statements and the Stock Returns of Listed Firms in Vietnam Stock Exchange
}

\author{
Ngoc Hung Dang ${ }^{1}$, Thi Viet Ha Hoang ${ }^{1} \&$ Manh Dung Tran ${ }^{2}$ \\ ${ }^{1}$ Hanoi University of Industry, Vietnam \\ ${ }^{2}$ National Economics University, Vietnam \\ Correspondence: Manh Dung Tran, Room No. 202, A14, Living quarter of National Economics University, Hai \\ Ba Trung District, Hanoi, Vietnam. Tel: 947-120-510. E-mail: tmdungktoan@yahoo.com
}

Received: July 19, 2017

Accepted: August 2, 2017

Online Published: August 25, 2017

doi:10.5539/ijef.v9n10p1

URL: https://doi.org/10.5539/ijef.v9n10p1

\begin{abstract}
This study is conducted to analyse the relationship between accounting information in the financial statements and the stock returns of listed firms in Vietnam Stock Market. Using OLS, FEM, REM, GLS, and GMM regression models, the study examines the relationship of earnings, volatility in the rate of return, size, levering ratios and growth rates to the stock returns of 274 firms in the period from 2012 to 2016. Findings from the study show that the rate of return, the change in the rate of return, gearing ratio and growth rate are positively correlated to the stock returns, while the size of firm by assets is negatively related to stock returns. Based on the research's results, the authors also provide some recommendations for investors, firm management and policy makers.
\end{abstract}

Keywords: accounting information, stock returns, Vietnam stock exchange

\section{Introduction}

In recent decades, a considerable volume of empirical studies has been carried out to examine the relationship between financial information and investors' decisions, including the study by Miller and Modigliani (1966). The findings show that income variables are the most important explanatory variable in valuation equations. In other words, accounting information has a strong positive correlation to investors' decisions. A related study by Ball $\&$ Brown (1968) investigates the usefulness of profitability information to investors' decisions by examining the impact of earnings per share (EPS) on the abnormal returns of stock.

Stock prices are influenced by a variety of factors, including the accounting information in the financial statements. In the developed securities markets, a number of researches has been conducted for finding empirical evidence related to the relationship between accounting information on financial statements and stock returns. Ball and Brown (1968), who carried out an empirical study to analyze this relationship between in the New York Stock Exchange, find that earnings disclosed in financial statements have considerable impacts on stock prices.

Basu (1983) investigated the relationship between income, market value and stock returns. Freeman (1987), Collins and Kothari (1989) and Easton and Harris (1991) conducted income models using income and stock return variables by examining the relationship between current earnings divided by opening stock price and stock return. Lipe et al. (1998), Dimitropoulos and Asteriou (2009), Cheng et al. (2013) used a time series earnings model to analyse impacts of regular earnings on the significance and volatility of earnings in explaining stock returns of listed firms.

In Vietnam, there has been many empirical studies carried out to examine the relationship between accounting information and stock prices, including Nguyen (2009), Nguyen (2011), Tran (2013), Ta (2015), Truong and Nguyen (2016), Nguyen (2016).

Due to different models using different constant and dependent variables, findings of these studies are not identical. The literature review shows that previous researches were conducted applying the basis of two different methods: (i) Using model in Ohlson (1995) such as Nguyen (2009), Nguyen (2011), Tran (2013), Truong and Nguyen (2016); or (ii) Using model in Easton and Harris (1991) such as Ta (2015), Tran (2015). 
These studies have established empirical evidence of the relationship between accounting information in the financial statements and stock returns.

This paper aims to examine whether the Easton and Harris (1991) model is relevant to the Vietnamese Stock Exchange and to further extend a number of control variables including size, gearing ratio, growth influences on stock returns based on models established in Freeman (1987), Collins and Kothari (1989), Easton and Zmijewski (1989), Collins et al. (1999). There are different regression models, such as OLS, FEM, FEM, GLS and GMM, applied in this study form ensuring effective estimations.

The research is structured as follows. Section 2 reviews the suitable literature. Section 3 presents hypotheses, research models and data. Section 4 sets out a discussion of key results, while Section 5 shows key conclusion and recommendations.

\section{Literature Review}

The relationship between accounting information in the financial statements and stock returns has received a lot of attentions. Ball and Brown (1968) studied the significance of profitability information to investors' decisions by examining impacts of EPS on abnormal returns of stocks. Basu (1983) focused on the relationship between earnings, market value and stock returns. Freeman (1987) investigates the relationship between stock returns and accounting earnings of large-scaled firms compared to small-scaled firms. Collins and Kothari (1989) examined factors influencing the relationship between stock returns and accounting information. Easton and Harris (1991) established a model employed income variables and stock returns variables by exploring the relationship between current earnings divided by the opening stock price and the stock returns.

Lipe et al. (1998) indicated that a non-linear relationship between stock returns and accounting earnings, the difference between losses and gains, and the difference among firms. Dimitropoulos and Asteriou (2009) focused on the relationship between accounting information on financial statements and financial indicators or stock prices of listed firms in the Greek Stock Exchange. Cheng et al. (2013) employed a time series of earnings model to examine whether regular earnings influence the role of earnings levels and the volatility of earnings on explaining stock returns using unobserved-component model to categorize earnings into regular earnings and temporary earnings. Angahar and Malizu (2015) investigated the relationship between revenues and the Nigerian Stock Exchange. Provided in Table 1 below is a summary of empirical studies that have been carried in the literature.

Table 1. Literature review of the relationship between accounting information and stock returns on a global scale

\begin{tabular}{|c|c|c|c|}
\hline Authors & eriod & Country & Main Results \\
\hline $\begin{array}{l}\text { Ball \& Brown } \\
(1968)\end{array}$ & $1957-1965$ & The United State & EPS has a positive correlation to stock returns. \\
\hline Basu (1983) & $1962-1978$ & The United State & $\begin{array}{l}\text { Shares of firms with high E/P ratio have higher risk-adjusted return ratios } \\
\text { compared to shares of firms with low E/P ratio. Shares of small-scaled firms yield } \\
\text { significantly higher returns than shares of larger-scale firms, with the effects of size } \\
\text { variables barely appearing when returns are controlled by risks and E/P ratio. }\end{array}$ \\
\hline $\begin{array}{c}\text { Freeman } \\
(1987)\end{array}$ & $1966-1982$ & The United State & $\begin{array}{l}\text { Security prices of large-scaled firms indicate accounting information in financial } \\
\text { statements earlier than smaller companies. } \\
\text { For a given level of unexpected earnings, the accumulative abnormal returns are } \\
\text { inversely correlated to the size of firms. } \\
\text { Security prices of large firms predict accounting earnings earlier than the security } \\
\text { prices of small firms, and the level of unexpected earnings associated with good or } \\
\text { bad news is inversely proportional to the business size. }\end{array}$ \\
\hline Collins \& & & & Interest rates and risk ratios have inverse effects on the relationship between stock \\
\hline $\begin{array}{c}\text { Kothari } \\
(1989)\end{array}$ & 1968-1982 & The United State & $\begin{array}{l}\text { returns and accounting information, while growth and profitability are positive } \\
\text { correlation. }\end{array}$ \\
\hline $\begin{array}{c}\text { Easton \& } \\
\text { Harris (1991) }\end{array}$ & 1969-1986 & The United State & $\begin{array}{l}\text { The results show that two forms of accounting earnings (current accounting } \\
\text { earnings and the volatility of accounting accounting compared to previous period) } \\
\text { play significant role in explaining stock returns. Accounting earnings also have } \\
\text { positive impacts on stock returns. }\end{array}$ \\
\hline $\begin{array}{l}\text { Dimitropoulos } \\
\text { \& Asteriou } \\
\text { (2009) }\end{array}$ & 1995-2004 & Greece & $\begin{array}{l}\text { The results demonstrate a negative relationship between the ratio of working } \\
\text { capital to total assets and returns on earnings, and a positive relationship of the } \\
\text { ratio of returns on earnings and revenues on total assets to stock returns. }\end{array}$ \\
\hline
\end{tabular}




\begin{tabular}{|c|c|c|c|}
\hline $\begin{array}{c}\text { Cheng et al. } \\
\text { (2013) }\end{array}$ & 1979-2009 & The United State & $\begin{array}{l}\text { Earnings levels provide better explanatory power for variations of stock returns } \\
\text { than earnings changes. Also, earnings levels are likely to predict earnings and stock } \\
\text { returns in the future. }\end{array}$ \\
\hline $\begin{array}{c}\text { Angahar \& } \\
\text { Malizu (2015) }\end{array}$ & 2011 & Nigeria & $\begin{array}{l}\text { There is a significant relationship between revenues and stock returns in the } \\
\text { Nigerian Stock Exchange. Thus, revenues are related to price and stock returns in } \\
\text { the Nigerian stock market, whereas changes in revenues have a negligible relation } \\
\text { to the stock returns. }\end{array}$ \\
\hline
\end{tabular}

In Vietnam, a number of research conducted by Nguyen (2009) have supported the relationship between accounting information and security prices in Vietnam stock market during the period from 2003 to 2007, Tran et al. (2015), Ta (2015). The results of empirical studies are presented in Table 2 as below.

Table 2. Literature review of the relationship between accounting information and stock returns in Vietnam context

\begin{tabular}{|c|c|c|c|}
\hline Authors & Period & Country & Main Results \\
\hline $\begin{array}{c}\text { Nguyen } \\
(2009)\end{array}$ & $2003-2007$ & Vietnam & $\begin{array}{l}\text { The results show that the relationship between accounting information and stock returns is } \\
\text { of statistical significance, although this relationship is weaker than most of other developed } \\
\text { and emerging markets. In addition, findings demonstrate that accounting information is the } \\
\text { best explanation for inflation-adjusted stock prices in the next } 3 \text { months. }\end{array}$ \\
\hline $\begin{array}{l}\text { Nguyen } \\
(2011)\end{array}$ & 2009 & Vietnam & $\begin{array}{l}\text { Factors in the examining model are related to accounting information and finance, } \\
\text { including book values, earnings per share (EPS), return on equity (ROE) and leverage. The } \\
\text { results show that only EPS and ROE have a positive correlation to the stock prices, yet the } \\
\text { explanation is not significant. }\end{array}$ \\
\hline $\begin{array}{c}\text { Tran et al. } \\
\text { (2015) }\end{array}$ & 2010-2013 & Vietnam & $\begin{array}{l}\text { The results indicate that there is a correlation between accounting information and stock } \\
\text { returns in Vietnam, but this correlation is slightly weak. In other words, the accounting } \\
\text { information is less useful for investors to make decisions in Vietnam stock market. }\end{array}$ \\
\hline Ta (2015) & 2009-2014 & Vietnam & $\begin{array}{l}\text { Accounting earnings are positively correlated to stock returns. The study also employs three } \\
\text { other characteristics of firms, namely size, gearing ratio and book-to-value price ratio to } \\
\text { examine the impact of these three factors on this relationship. }\end{array}$ \\
\hline Tran (2015) & 2009-2014 & Vietnam & $\begin{array}{l}\text { The results show that there is evidence of a positive impact of accounting information on } \\
\text { stock returns in Vietnam stock market in the long term. } \\
\text { The paper examines the relevance of Easton and Harris (1991) model. } \\
\text { The regression results show that earnings ratios and variable earnings ratio have positive } \\
\text { relations to the stock returns. Also, factors of scale, gearing ratio have positive impact } \\
\text { where growth rates have negative impacts on the relationship between accounting } \\
\text { information on financial statements and the stock returns in the Vietnam stock market. }\end{array}$ \\
\hline
\end{tabular}

In general, the relationship between accounting information in the financial statements and the stock returns has been significantly examined on a global scale. In Vietnam, researches on this issue have been done adopting different models. In particular, Nguyen's study (2009) is merely based on Ohlson's (1995) price model. Meanwhile, Nguyen (2011) employed a regression model using data collected in 2009, thus the study fails to evaluate the market in overall. Tran et al. (2015) applied the Easton and Harris model (1991), but the correlation was weak and only implemented on 108 firms on Hanoi Stock Exchange (HOSE). Ta (2015), Tran (2015) also adopted the OLS regression model as carried out in Easton \& Harris (1991).

According to findings in the literature, there is evidence of the relationship between accounting information in financial statements and stock returns. However, these studies are mainly based on different theories, models and data collection methods.

\section{Hypotheses, Research Model and Data}

\subsection{Hypotheses}

In an efficient market, stock prices are unpredictable, hence stock returns are random and usually in a normal distribution. The market is divided into three levels of efficiency: (i) the weak form, (ii) the semi-strong form, and (iii) the strong form. The weak form implies a market where the current stock price fully reflects historical price information. The semi-strong form reflects the current price of a stock fully reveals published information 
and information about the company such as profitability, dividends, management representations. The strong form of efficiency indicates that it is impossible to enforce commercial transactions based on insider information which is fully reflected on the market price (Fama, 1970).

\subsubsection{Earnings Ratios and Volatility of Earnings Ratio}

According to Easton and Zmijewski (1989), Collins and Kothari (1989) argue that the relationship between stock returns and accounting earnings exists because stock price is a function of expected dividends in the future.

Stock prices change subject to the adjustments of expected dividends in the future based on expected stock returns. The ERC coefficient ( $\beta$ ) is an important variable in the linear model considering the relationship between stock returns and accounting information in the financial statements (represented by profitability information) because it implies the extent to which earnings influence on the stock returns. Easton and Harris (1991) found that earnings and its changes simultaneously explain the stock returns variables.

In this paper, the stock return is represented by two main variables: earnings ratio and changes in the earnings ratio. Based on research conducted by Easton and Harris (1991), the accounting information represented by the earnings ratio and the variable earnings rate has positive impacts on the stock returns, hence the authors establish two hypotheses $\mathrm{H} 1$ and $\mathrm{H} 2$ as follows:

\section{Hypothesis H1: The earnings ratio has positive impacts on the stock returns.}

\section{Hypothesis H2: Changes in the earnings ratio have positive impacts on the stock returns.}

\subsubsection{Scale}

Firm size is one of the key characteristics used in the literature to research on the correlated relationship between accounting information in the financial statements and stock returns. The studies show that firm size impacted on this relationship. The firm size is measured by the natural logarithm of total assets (Collins \& Kothari, 1989). Basu (1983) showed that stocks of small-scaled firms yield significantly higher stock returns than that of the larger ones, and that the effects of scale variables is weakened if the stock returns are controlled by risks and E/P ratio. According to Freeman (1987), there are differences in the impacts of accounting information between large and small firms.

Stock prices of small firms are affected followed by the stock prices of large ones and the significance of stock returns' fluctuations around the time of disclosure of small firms is larger than that of large ones. Easton and Zmijewski (1989) show that the firm' size is positively impacted on the relationship between accounting information on financial statements and the stock returns. Large-scaled firms are normally less risky than small-scaled ones, thus they are likely to have lower expected stock returns and to better react to new information on the market. Moreover, large firms tend to publish more information on earnings-released dates (Easton \& Zmijewski, 1989). Collins and Kothari (1989) also demonstrated that the relationship between accounting information and stock returns varies with the firm's size.

Hypothesis H3: The firm's size has negative impacts on the relationship between accounting information and stock returns.

\subsubsection{Leverage Ratio}

According to Dhaliwal et al. (1991), the firm's risk is measured by the ratio of debts or financial leverage. Financial leverage is the ratio of total debts to total assets of a company. Collins and Kothari's (1989) considered influencing factors on the relationship between accounting information and stock returns including the risk-free rate, the risk level, the residuals of accounting earnings. The cost of capital increases with interest rate and risk. Collins and Kothari (1989) found out that the risk-free rate and the systematic risk were negatively correlated to this relationship. The higher the debt, the higher the risk. In other words, gearing ratio has a negative impact on the relationship between accounting information and stock returns. Easton and Zmijewski (1989) also found similar results when examining the debt ratio, the beta factor and the relationship between accounting information and stock returns. Dhaliwal et al. (1991) argued that ERC is inversely related to levering ratio. Firms with medium leverage have higher total debts than total capital. Therefore, creditors or stockholders are likely to gain more advantages in the event of increasing earnings.

Hypothesis H4: Gearing ratio has negative impacts on the relationship between accounting information and stock returns.

\subsubsection{Growth}

Market to book value of equity ratio has been measured the firm's growth (Collins \& Kothari, 1989; Collins et 
al., 1999). Collins and Kothari (1989) argued that the profitability and growth opportunities are related to the ERC, i.e. the growth consists of the residual earnings and growth opportunities. Collins and Kothari (1989) explained the relationship between accounting information and stock returns is related to the firm's growth and found that the higher the growth rate, the higher the ERC. According to Fama and French (1993), large-scaled stock listings with high BE/ME (book value divided by market value) value generates higher returns than small-scaled stock listings with high BE/ME value. To measure growth, Collins et al. (1999) employed MB ratio.

Hypothesis H5: Growth has positive impacts on the relationship between accounting information and stock returns.

\subsection{Research Model}

Based on the literature review and the adoption of the Easton \& Harris (1991) model to examine empirical data collected on the Vietnam Stock Exchange, two regression models are represented as follows:

Model 1: $S R_{i t}=\beta_{0}+\beta_{1} \frac{E P S_{-} P_{i t}}{P_{i t-1}}+\beta_{2} \frac{D E P S_{-} P_{i t}}{P_{i t-1}}+U_{i t}$

Model 2: $S R_{i t}=\beta_{0}+\beta_{1} \frac{E P S_{-} P_{i t}}{P_{i t-1}}+\beta_{2} \frac{D E P S_{-} P_{i t}}{P_{i t-1}}+\beta_{3} S I Z E_{i t}+\beta_{4} L R_{i t}+\beta_{5} M B_{i t}+U_{i t}$

$\beta_{0}:$ Intercept;

$\beta_{1,} \beta_{2,} \beta_{3,} \beta_{4,} \beta_{5}$ : Regression coefficients;

$U_{i t}:$ Random error.

The variables in model 1 are explained and measured in Table 3.

Table 3. Independent and dependent variables

\begin{tabular}{|c|c|c|c|c|}
\hline Symbol & Variables & Types & Measurement & Expected correlation \\
\hline $\mathrm{SR}_{\mathrm{it}}$ & Returns on stock i year $\mathrm{t}$ & Dependent & $S R_{i t}=\log \left(\frac{P_{i t}}{P_{i t-1}}\right)$ & \\
\hline$E P S_{-} P_{i t}$ & Earnings ratios of firm $\mathrm{i}$ year $\mathrm{t}$ & Independent & $E P S_{-} P_{i t}=\frac{E P S_{i t}}{P_{i t-1}}$ & + \\
\hline$D E P S_{-} P_{i t}$ & Change in earnings ratio of firm i year $t$ & Independent & $D E P S_{-} P_{i t}=\frac{E P S_{i t}-E P S_{i t-1}}{P_{i t-1}}$ & + \\
\hline$S I Z E_{i t}$ & Scale of firm i year $\mathrm{t}$ & Controlled & $S I Z E_{i t}=\log ($ Assets $)$ & - \\
\hline$L R_{i t}$ & Gearing ratio of firm i year $\mathrm{t}$ & Controlled & $L R_{i t}=$ Total debts $/$ Total assets & - \\
\hline$M B_{i t}$ & Growth rate of firm i year $\mathrm{t}$ & Controlled & $\begin{array}{l}M B_{i t}=\text { Market value/Book } \\
\text { value }\end{array}$ & + \\
\hline
\end{tabular}

\subsection{Research Data}

Research data are secondary data collected from audited financial statements of 274 listed firms on Ho Chi Minh Stock Exchange and Hanoi Stock Exchange in the period from 2012 to 2016. Total observations are 1,370 (274 firms x 5 years). Key inputs include earnings per share (EPS), stock prices after 3 months of year end, total assets, total liabilities, market value and book value of each firm collected from cophieu68's database.

Data analysis: The study uses panel data for the established econometric model to examine the relationship between accounting information on the financial statements and the stock returns of listed firms on Vietnam Stock Exchange. The adopted regression methods consist of Ordinary least square (OLS) regression method, Fixed effects model (FEM) regression approach, and Random effects model (REM) regression. After employing the regression method appropriate to the model, the authors examine the reliability of the selected model. In cases where the model's defection is violated hypothetically, the author will apply the Generalized least square (GLS) regression and the Generalized methods of moment (GMM) regression methods. When the number of samples matching the estimated value of $\beta$, the estimated value will be closer to its actual value. Estimating GMM will generate estimated values subject to the normal distribution, which is a crucial attribute because it is the basis to form confidence bands and other evaluation. The GMM method also results in effectively estimated values, i.e. the average variance extracted in the estimation model is minimal.

\section{Results and Discussion}

Statistical data as demonstrated on Table 4 show that the average stock return is $20.99 \%$, with the lowest value of negative $-130 \%$ and the highest value of $236 \%$. The average earnings ratio is $29.65 \%$, while the change in the 
average earnings is $-0.13 \%$. The average debt ratio of listed firms is $48.32 \%$ and the average growth of enterprises is $95.76 \%$.

Table 4. Descriptive statistics of variables

\begin{tabular}{lccccc}
\hline & Number of observations & Average value & Standard Deviation & Minimum value & Maximum value \\
\hline SR & 1370 & 0.2098832 & 0.3682186 & -1.3 & 2.36 \\
EPS_P & 1370 & 0.2965474 & 0.3114536 & -1.78 & 2.97 \\
DEPS_P & 1370 & -0.0013066 & 0.2362496 & -1.45 & 2.68 \\
SIZE & 1370 & 13.24063 & 1.524538 & 9.45 & 19.01 \\
LR & 1370 & 0.4832701 & 0.222799 & 0 & 0.97 \\
MB & 1370 & 0.9576569 & 0.720325 & 0.08 & 9.35 \\
\hline
\end{tabular}

Table 5 shows the result of the correlation coefficient amongst variables, the target of examining the relationship between the independent variables and dependant variables to eliminate factors that might result in no multicollinearity before running the regression, the correlation coefficients amongst independent variables in the model are less than 0.8 . Thus, there is unlikely to have no multicollinearity amongst independent variables, which is tested by using VIF.

Table 5. Autocorrelation matrix

\begin{tabular}{lrrrrrr}
\hline & \multicolumn{1}{c}{ SR } & \multicolumn{1}{c}{ EPS_P } & \multicolumn{1}{c}{ DEPS_P } & SIZE & LR & MB \\
\hline SR & 1 & & & & & \\
EPS_P & 0.4179 & 1 & & & & \\
DEPS_P & 0.4214 & 0.3141 & -0.0813 & -0.0211 & 1 & \\
SIZE & -0.0448 & 0.0292 & -0.0213 & 0.3533 & 1 & \\
LR & -0.0438 & -0.019 & 0.0894 & 0.125 & -0.2145 & 1 \\
MB & 0.2729 & & & & & \\
\hline
\end{tabular}

The multicollinearity being tested with the variance multiplier indicates that the VIF mean of the variables in the model is 1.16, less than 10. According to Baltagi (2008), if the model has no VIF of independent variables with value more than 10 , there is no multicollinearity.

Table 6. Test of multicollinearity

\begin{tabular}{lcc}
\hline & VIF & $1 /$ VIF \\
\hline SR & 1.24 & 0.804073 \\
REPS & 1.21 & 0.824993 \\
DEPS & 1.12 & 0.890926 \\
SIZE & 1.12 & 0.892139 \\
LR & 1.11 & 0.899782 \\
MB & 1.16 & \\
Mean VIF & $\mathbf{1 . 1 6}$ & \\
\hline
\end{tabular}

With regard to Model 1, excluding control variables, we compare 3 types of regression models, including OLS, FEM and REM, to adopt the most appropriate model by using F test and the Hausman test.

$\mathrm{F}$ test shows that Prob $>\mathrm{F}=0.000<\alpha=5 \%$, so with the significance level of $5 \%$ we reject $\mathrm{H}_{0}$. That is, with the data collected subject to the existence of fixed effects in each firm over time, indicating that the FEM regression model is appropriate and OLS is inappropriate.

Based on the results of running FEM and REM regression models, the Hausman test is employed to compare these two regression models. The Hausman test results are demonstrated in Table 7, indicating that Prob $>$ chi $2=$ $0.9239>=5 \%$, thus it is not statistically significant to reject the $\mathrm{H}_{0}$ hypothesis is, i.e. the REM is more appropriate than the FEM.

Before analyzing influencing factors of accounting information to stock factors, we test on: heteroskedasticity, 
autocorrelation and necessary adjustments to correct the model's errors.

To test whether there is heteroskedasticity, the Breusch and Pagan tests are adopted. We establish two hypotheses: $\mathrm{H}_{0}$ : there is no heteroskedasticity; $\mathrm{H}_{1}$ : there is heteroskedasticity. The results show that p-values are equal to $1.0000>\alpha(5 \%)$, indicating that we fail to reject the hypothesis $\mathrm{H}_{0}$. The Wooldridge test is used to test whether there is autocorrelation in adopted regression models. The results demonstrate that $\mathrm{p}$-value $=0.0067<\alpha=0.05$, indicating that $\mathrm{H}_{0}$ is rejected, i.e there is autocorrelations. After deciding to employ REM model, we correct the detected defects of the REM model by adopting the GLS and GMM methods. The results are demonstrated in Table 7.

As shown on Table 7, the variables of earnings ratio and changes in earnings ratios have positive effects on the stock returns at level of statistical significance of $1 \%$. Hence, both hypotheses $\mathrm{H}_{1}$ and $\mathrm{H}_{2}$ are accepted.

Table 7. Descriptive statistics of regression model 1

\begin{tabular}{|c|c|c|c|c|c|}
\hline & $\begin{array}{c}\text { OLS regression } \\
\text { model }\end{array}$ & $\begin{array}{c}\text { FEM regression } \\
\text { model }\end{array}$ & $\begin{array}{c}\text { REM regression } \\
\text { model }\end{array}$ & $\begin{array}{c}\text { GLS regression } \\
\text { model }\end{array}$ & $\begin{array}{c}\text { GMM regression } \\
\text { model }\end{array}$ \\
\hline EPS_P & $\begin{array}{c}0.375 * * * \\
{[13.00]}\end{array}$ & $\begin{array}{c}0.386 * * * \\
{[9.37]}\end{array}$ & $\begin{array}{c}0.375 * * * \\
{[13.00]}\end{array}$ & $\begin{array}{c}0.425 * * * \\
{[20.31]}\end{array}$ & $\begin{array}{c}0.297 * * * \\
{[3.19]}\end{array}$ \\
\hline DEPS_P & $\begin{array}{c}0.502 * * * \\
{[13.21]}\end{array}$ & $\begin{array}{c}0.498 * * * \\
{[11.51]}\end{array}$ & $\begin{array}{c}0.502 * * * \\
{[13.21]}\end{array}$ & $\begin{array}{c}0.497 * * * \\
{[15.69]}\end{array}$ & $\begin{array}{c}0.306^{* *} \\
{[2.10]}\end{array}$ \\
\hline L.SR & & & & & $\begin{array}{c}-0.123^{* *} \\
{[-2.18]}\end{array}$ \\
\hline _cons & $\begin{array}{c}0.0995 * * * \\
{[8.24]}\end{array}$ & $\begin{array}{c}0.0960 * * * \\
{[6.33]}\end{array}$ & $\begin{array}{c}0.0995 * * * \\
{[8.24]}\end{array}$ & $\begin{array}{c}0.0914 * * * \\
{[11.54]}\end{array}$ & $\begin{array}{c}0.163 * * * \\
{[9.44]}\end{array}$ \\
\hline $\begin{array}{l}\mathrm{N} \\
\mathrm{R}-\mathrm{sq} \\
\end{array}$ & $\begin{array}{r}1370 \\
0.268 \\
\end{array}$ & $\begin{array}{l}1370 \\
0.237 \\
\end{array}$ & $\begin{array}{r}1370 \\
0.268 \\
\end{array}$ & 1370 & 1370 \\
\hline $\mathrm{F}$ test & $\begin{array}{c}F(2,1367)=250.29 \\
\text { Prob }>F=0.0000\end{array}$ & $\begin{array}{c}F(2,1094)=169.81 \\
\text { Prob }>F=0.0000\end{array}$ & & & \\
\hline LM test & & & $\begin{array}{l}\text { Wald chi } 2(2)=500.58 \\
\text { Prob }>\text { chi } 2=0.0000\end{array}$ & $\begin{array}{l}\text { Wald chi2 } 2(2)=928.06 \\
\text { Prob }>\text { chi } 2=0.0000\end{array}$ & $\begin{array}{l}\text { Wald } \operatorname{chi} 2(3)=52.44 \\
\text { Prob }>\text { chi } 2=0.0000\end{array}$ \\
\hline Hausman test & & $\begin{array}{r}\text { chi2( } \\
\text { Prob }>\text { ch }\end{array}$ & $\begin{array}{l}=0.16 \\
2=0.9239\end{array}$ & & \\
\hline Breusch and & & chibar2 & $01)=0.00$ & & \\
\hline Pagan Lagrangian & & Prob $>$ chi & $\operatorname{ar} 2=1.0000$ & & \\
\hline Wooldridge test & & $\begin{array}{l}\mathrm{F}(1,27 \\
\text { Prob > }\end{array}$ & $\begin{array}{l}=7.469 \\
=0.0067\end{array}$ & & \\
\hline
\end{tabular}

Note. $\mathrm{t}$ statistics in brackets $* \mathrm{p}<0.1, * * \mathrm{p}<0.05, * * * \mathrm{p}<0.01$.

Considering model 2, with the addition of control variables including scale variables, debt ratios and growth, Hausman's test results are shown in Table 8. It is observed that p-value $=0.0000<\alpha=5 \%$, thus the FEM regression model is appropriate.

In order to test whether there is heteroskedasticity in the adopted model, we use the Modified Wald test. The results indicate that $\mathrm{p}$-value $=0.000<\alpha=5 \%$, i.e. there is heteroskedasticity. Therefore, the authors correct the model's errors by employing GLS and GMM regression methods.

According to Table 8, the earnings ratio and change in the earnings ratio have positive effect on the stock returns at level of statistical significance of $1 \%$. Thus, both hypotheses $\mathrm{H} 1$ and $\mathrm{H} 2$ are accepted in Model 2. In terms of GMM regression model, all control variables are statistically significant at $1 \%$. Particularly, the scale variable is positively correlated with the stock returns, thus hypothesis $\mathrm{H}_{3}$ is consistent with the original proposition. Debt ratios are positively correlated with TSSL, indicating a rejection of the hypothesis $\mathrm{H}_{4}$. Firm's growth shows a positive correlation with the stock returns, hence the hypothesis $\mathrm{H}_{5}$ is accepted. 
Table 8. Descriptive statistics of regression model 2

\begin{tabular}{|c|c|c|c|c|c|}
\hline & $\begin{array}{c}\text { OLS regression } \\
\text { model }\end{array}$ & $\begin{array}{c}\text { FEM regression } \\
\text { model }\end{array}$ & $\begin{array}{c}\text { REM regression } \\
\text { model }\end{array}$ & $\begin{array}{c}\text { GLS regression } \\
\text { model }\end{array}$ & $\begin{array}{c}\text { GMM regression } \\
\text { model }\end{array}$ \\
\hline \multirow{2}{*}{ REPS_P } & $0.384 * * *$ & $0.428 * * *$ & $0.384 * * *$ & $0.437 * * *$ & $0.237 * *$ \\
\hline & {$[13.88]$} & [10.49] & {$[13.88]$} & [20.97] & {$[2.52]$} \\
\hline \multirow{2}{*}{ DEPS-P } & $0.460^{* * *}$ & $0.448^{* * *}$ & $0.460 * * *$ & $0.452 * * *$ & $0.395^{* * *}$ \\
\hline & {$[12.61]$} & [10.83] & {$[12.61]$} & [15.09] & {$[3.00]$} \\
\hline \multirow{2}{*}{ SIZE } & $-0.0135 * *$ & $-0.241 * * *$ & $-0.0135^{* *}$ & $-0.0142 * * *$ & $-0.423 * * *$ \\
\hline & {$[-2.30]$} & {$[-4.83]$} & {$[-2.30]$} & {$[-3.67]$} & {$[-3.66]$} \\
\hline \multirow{2}{*}{ LR } & 0.0493 & $0.581 * * *$ & 0.0493 & $0.0437^{*}$ & $0.863 * * *$ \\
\hline & {$[1.21]$} & {$[3.73]$} & [1.21] & {$[1.68]$} & [2.64] \\
\hline \multirow{2}{*}{ MB } & $0.136^{* * *}$ & $0.221 * * *$ & $0.136^{* * *}$ & $0.115^{* * *}$ & $0.395^{* * *}$ \\
\hline & {$[11.42]$} & [11.57] & {$[11.42]$} & [13.47] & [6.84] \\
\hline \multirow{2}{*}{ L.SR } & L.sr & & & & -0.00684 \\
\hline & & & & & {$[-0.13]$} \\
\hline \multirow{2}{*}{ _cons } & $0.121^{*}$ & $2.776 * * *$ & $0.121 *$ & $0.146^{* * *}$ & $4.941 * * *$ \\
\hline & [1.66] & {$[4.46]$} & [1.66] & [3.09] & {$[3.48]$} \\
\hline $\mathrm{N}$ & 1370 & 1370 & 1370 & 1370 & 822 \\
\hline $\mathrm{R}$-sq & 0.334 & 0.322 & & & \\
\hline \multirow{2}{*}{ F test } & $\mathrm{F}(5,1364)=136.76$ & $\mathrm{~F}(5,1091)=103.44$ & & & \\
\hline & Prob $>F=0.0000$ & Prob $>F=0.0000$ & & & \\
\hline \multirow{2}{*}{ LM test } & & & Wald chi2 $(5)=1164.08$ & Wald chi2 $(6)=98.11$ & \\
\hline & & & Prob $>$ chi $2=0.0000$ & Prob $>$ chi $2=0.0000$ & \\
\hline \multirow{2}{*}{ Hausman's test } & \multicolumn{5}{|c|}{$\operatorname{chi} 2(6)=42.80$} \\
\hline & \multicolumn{5}{|c|}{ Prob $>$ chi $2=0.0000$} \\
\hline \multirow{2}{*}{$\begin{array}{l}\text { Modified Wald } \\
\text { test }\end{array}$} & \multicolumn{5}{|c|}{$\operatorname{chi} 2(661)=24692.33$} \\
\hline & \multicolumn{5}{|c|}{ Prob $>$ chi $2=0.0000$} \\
\hline \multicolumn{2}{|l|}{ Wooldridge } & \multicolumn{2}{|c|}{$F(1,660)=2.690$} & & \\
\hline test & & \multicolumn{2}{|c|}{ Prob $>F=0.1021$} & & \\
\hline
\end{tabular}

Note. $\mathrm{t}$ statistics in brackets $* \mathrm{p}<0.1, * * \mathrm{p}<0.05, * * * \mathrm{p}<0.01$.

Based on findings from the regression models, we propose some discussions as follows:

First, earnings ratio factor (EPS_P) is positively correlated with the stock returns $1 \%$ statistically significant, consistent with the hypothesis $\mathrm{H}_{1}$. This result implies that the model established in Easton and Harris (1991) is suitable to the case of the Vietnam stock market, which also have been supported by other empirical researches, such as Ball and Brown (1968), Basu (1983), Ta (2015) and Tran (2015).

Second, the scale factor (SIZE) demonstrates a positive and statistically significant correlation at $1 \%$ statistical significance to the stock returns, consistent with the hypothesis $\mathrm{H}_{3}$. Other studies also have similar findings, such as Lipe et al. (1998), Dimitropoulos and Asteriou (2009), Cheng et al. (2013).

Third. the debt-to-equity ratio (LR) shows a positive regression result at $1 \%$ statistically significance in relation to the stock returns, which is contrast to the hypothesis $\mathrm{H}_{4}$. The results of this study are not consistent with those of Freeman (1987), Collins and Kothari (1989), Ta (2015), Tran (2015).

Fourth, the growth factor (MB) has a positive effect on the stock returns, tested at $1 \%$ statistically significance. This result is consistent with the hypothesis $\mathrm{H}_{5}$, which is agreed with findings of Collins and Kothari (1989).

\section{Conclusions and Recommendations}

The empirical study use a sample comprising of 1,370 observations, collected from 274 listed companies on the Vietnam stock market from 2012 to 2016. There are different regression methods adopted, including OLS, FEM, REM with independent variables: earnings ratios (EPS_P), change in earnings ratios (DEPS_P) and control variables namely asset size (SIZE), debt ratio (LR) and growth (MB). In order to correct errors such as heteroskedasticity, autocorrelations, we also employ GLS and GMM regression models. The results using the GMM method indicate that the EPS_P, DEPS_P, LR, MB variables have positive effects on the stock returns, whereas the SIZE variable shows negative impact on the stock returns. Based on these findings, we propose some recommendations as follows: 
For investors, it is important to consider the accounting information such as EPS on the financial statements when making investment decisions. However, there are many other factors that have influenced the stock returns. Also, published accounting information have not significantly affected the stock market volatility in Vietnam current stock market (adjusted $\mathrm{R}^{2}$ explained only $33.3 \%$ ). Before investing in a stock, investors should consider the EPS over the share price ratio and the volatility of the EPS over the share price ratio. If these two variables rise, the stock returns will increase and vice versa. Moreover, other financial information should be also of significance to the investors' decisions. This empirical research provides an important implication on the difference amongst firms generating returns at the same level.

There should be a full, accurate and timely disclosure of financial statements, audit reports and the Boards' report for investors to make better investment decisions. This not only builds investors' confidence in the financial institutions' transparency, but also increases the corporations' values in order to attract more potential investors.

The best time to take the relationship between accounting information on financial statements and stock returns into account when making investment decisions is after 3 months of ending the fiscal year (31/03). Corporations need to disclose financial reports on time because investors are likely to make crucial investment decisions at this time.

\section{References}

Angahar, P. A., \& Malizu, J. (2015). The Relationship between Accounting Information and Stock Market Returns on the Nigerian Stock Exchange. Management and Administrative Sciences Review, 4(1), 76-86.

Ball, R., \& Brown, P. (1968). An empirical evaluation of accounting income numbers. Journal of Accounting Research, 6(2), 159-178. https://doi.org/10.2307/2490232

Basu, S. (1983). The relationship between earnings' yield, market value and return for NYSE common stocks:

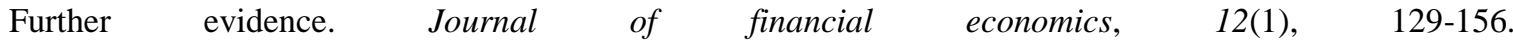
https://doi.org/10.1016/0304-405X(83)90031-4

Cheng, C. S., Lee, B. S., \& Yang, S. (2013). The value relevance of earnings levels in the return-earnings relation. International Journal of Accounting and Information Management, 21(4), 260-284. https://doi.org/10.1108/IJAIM-04-2012-0019

Collins, D. W., \& Kothari, S. P. (1989). An analysis of intertemporal and cross-sectional determinants of earnings response coefficients. Journal of Accounting and Economics, 11(2), 143-181. https://doi.org/10.1016/0165-4101(89)90004-9

Collins, D. W., Pincus, M., \& Xie, H. (1999). Equity valuation and negative earnings: The role of book value of equity. The Accounting Review, 29-61. https://doi.org/10.2308/accr.1999.74.1.29

Dimitropoulos, P. E., \& Asteriou, D. (2009). The value relevance of financial statements and their impact on stock prices: Evidence from Greece. Managerial Auditing Journal, 24(3), 248-265. https://doi.org/10.1108/02686900910941131

Easton, P. D., \& Harris, T. S. (1991). Earnings as an explanatory variable for returns. Journal of Accounting Research, 19-36. https://doi.org/10.2307/2491026

Easton, P. D., \& Zmijewski, M. E. (1989). Cross-sectional variation in the stock market response to accounting earnings announcements. Journal of Accounting and Economics, 11(2), 117-141. https://doi.org/10.1016/0165-4101(89)90003-7

Fama, E. F. (1970). Efficient capital markets: A review of theory and empirical work. The journal of Finance, 25(2), 383-417. https://doi.org/10.2307/2325486

Freeman, R. N. (1987). The association between accounting earnings and security returns for large and small firms. Journal of Accounting and Economics, 9(2), 195-228. https://doi.org/10.1016/0165-4101(87)90005-X

Hai, T. T. T., Diem, N. N., \& Binh, H. Q. (2015). The Relationship between Accounting Information Reported In Financial Statements and Stock Returns: Empirical Evidence from Vietnam. International Journal of Accounting and Financial Reporting, 5(1), 229. https://doi.org/10.5296/ijafr.v5i1.7473

Lipe, R. C., Bryant, L., \& Widener, S. K. (1998). Do nonlinearity, firm-specific coefficients, and losses represent distinct factors in the relation between stock returns and accounting earnings? Journal of Accounting and Economics, 25(2), 195-214. https://doi.org/10.1016/S0165-4101(98)00022-6 
Miller, M. H., \& Modigliani, F. (1966). Some estimates of the cost of capital to the electric utility industry, 1954-57. The American Economic Review, 333-391.

Nguyen, T. H. N. (2016). Affecting of financial information in the financial reports to tock prices of listed firms. Journal of Economics \& Development, 226(II), 118-122.

Nguyen, T. K. P. (2016). Relationship between financial information and stock prices of listed firms in the Vietnam Stock Exchange. PhD Thesis, National Economics University.

Nguyen, T. T. D. (2011). Affecting of accounting information and financial ratios to stock prices in the Vietnam Stock Exchange. Journal of Banking Technology, 62, 23-27.

Nguyen, V. D. (2009). Relationship between financial data in the financial statements and stock prices: Using modern theories in Vietnamese context. Journal of Economic Research, 375, 18-31.

Ohlson, J. (1995). Earnings, book values and dividends in equity valuation. Contemporary Accounting Research, 11, 661-687. https://doi.org/10.1111/j.1911-3846.1995.tb00461.x

Ta, T. D. P. (2015). Evidence of impact of accounting profit on profitability ratio of stocks and factors affecting this relationship in the Vietnam Stock Exchange. Master Thesis, Ho Chi Minh Economics University.

Tran, N. L. (2013). Factors affecting the relationship between stock prices and financial data of Vietnamese firms. Master Thesis, Ho Chi Minh Economics University.

Tran, T. M. H. (2015). Relationship between accounting information and profitability ratios of listed firms. Master Thesis, Ho Chi Minh Economics University.

Truong, D. L., \& Nguyen, M. N. (2016). Affecting of accounting information to stock prices in Hanoi Stock Exchange. Journal of Banking Technology, 126, 35-42.

\section{Copyrights}

Copyright for this article is retained by the author(s), with first publication rights granted to the journal.

This is an open-access article distributed under the terms and conditions of the Creative Commons Attribution license (http://creativecommons.org/licenses/by/4.0/). 